\begin{tabular}{lcc}
\hline \multicolumn{2}{c}{ A N N A L E S } \\
UNIVERSITATIS MARIAE CURIE-SKŁODOWSKA \\
LUBLIN - POLONIA \\
VOL. XXV, 2 & SECTIOK \\
\hline
\end{tabular}

Borys Grinchenko Kyiv University. Professional Governmental Association (PGA)

\author{
VICTORIA VDOVYCHENKO
}

ORCID ID: https://orcid.org/0000-0002-7000-3843

\title{
Through the Lenses of Italy's Euroscepticism or a Tale for the Future of the European Integration Project
}

\begin{abstract}
The relationship between the European Union (EU) and its member states have been characterized by many significant changes when the impact of the Euroscepticism started to mark its presence in the number of countries, founding members of the European Union. The author will try to analyze the Eurosceptic developments in Italy in the last years, with a particular focus on the 2018 when the new "yellow-green" government coalition was formed. The unpredictable results waving to the anti-establishment political elites coming to power demonstrate that the shifts in "national lenses" started to be a trend with unpredictable results not only for Italy, but for the whole EU. By analyzing the wide-range levels of Euroscepticism, the author will try to reveal how the multi-faceted concept of Euroscepticism casts shades on the European integration project.
\end{abstract}

Key words: Euroscepticism, Italy, the Italian Republic, the European Union (EU), European integration

\section{INTRODUCTION}

The arc of contemporary politics bends towards delusion because the so-called politically "dark forces" of world politics - nationalism, territorial revision, illiberalism - are reasserting themselves as vital voices making an impact for the governments to change their behavior in addressing the challenges. As a result, the nations are rethinking about the European project as well, expanding the grounds for Euroscepticism and populism to be strong.

The turning point in this respect was 2014 when the European Parliament received a new impetus of Eurosceptic representatives coming to power. Apart from 
UK Independence Party and Front Nationale (France), there appeared to be the representatives of Five Star Movement (Movimento 5 Stelle, M5S) and (Northern) League (Lega) from Italy. Moreover, at the national level in Italy since June 2018, new rules of procedure are changing the spectrum of the country from genuinely Euro-optimistic to Eurosceptic interlinked with the proposed budget rules to the EU.

The relevance of this topic lies from the need to shape the new populism in Europe overwhelming EU member states' decision-making and not trajectoring much towards the European integration project. In this respect, Italy presents a unique case combining not only populistic trends but also uniting them with the Eurosceptic decision from the newly formed "yellow-green" government. This paper aims to show how the elements of populism and Euroscepticism are interlinked in what concerns Italian ruling coalition since June 2018. This paper is structured into four parts. In the first section, a theoretical reflection on the concepts of Euroscepticism is provided to individuate the dimensions common to the two phenomena. The second section tells about the shift in the Italian discourse from Euro-optimism to Euro-scepticism in particular after Matteo Renzi's referendum in 2016. The third and fourth sections are dedicated to clarifying the research questions: 1) In what way is the Italian populism and Euroscepticism different?; 2) What implications does this hybrid combination of populism and Euroscepticism put on the position of Italy towards the European integration project, in particular, relevant before the European parliamentary elections in 2019 and after 100 days of yellow-green governance?

The novelty of this research paper is about to try to summarize the Italian populism upheaval corresponding to the "yellow-green" governance and Eurosceptic trends in decision-making. The primary source of the research paper was the governmental program of yellow-green government composed by the League and Five Star Movement in June 2018 as well as some legal, governmental acts. Moreover, we use the political parties programs (with the focus on the League and Five Star Movement) to summarize the points related to the issues of the EU, economy, and migration. The secondary sources of the paper measure the attractiveness of the governmental decisions in what concerns sensitive issues to Italians: budget talks, migration challenges, and social spending. The methodology of the paper includes a desk study of documents and publications from most primary and secondary sources helping to evaluate a study's overall validity and reliability critically.

The article ends up with reflections on further research studies. Based on the collection of single-country and comparative member-states studies, we formulated our conclusions revealing the grounds for Italian populist Euroscepticism and proved the hypothesis. 


\section{EUROPEAN INTEGRATION AND EUROPEAN SKEPTICISM}

European integration became mainstream for the majority of the countries of the EU especially in the last decade. However, the grounds were strong enough even in 1991. That time, encompassing domestic and foreign challenges, the European Union was an innovative crafting model aimed at incubating sustainability, prosperity and sharing common values. The diverse voices to interpret the Maastricht Treaty, its content and implementation, led to the first waves of Eurosceptic approaches. Due to the multifaceted challenges, nations feared to lose national sovereignty as well as national identity especially when the European citizenship project turned to be real [Verney 2011: 1-2]. In reality, the implementation process of the Maastricht Treaty entered into the period of elections, party competitions, and referendums.

Such transformation in the European Union prompted the scholars to be focused on various aspects within Euroscepticism interpretation. In general, Euroscepticism as a phenomenon is being understood as skepticism towards the process of the disapproval concerning one or some European Union policies.

One of the conventional explanation for Euroscepticism was related to the EU democratic deficit existence. It means that EU decision-making process was far from the aware citizen model when citizens were able to present their voices. It is necessary to admit that, as a political phenomenon, Euroscepticism received a limited level of interest till recent times. In this regard, some of the scholars, like Paul Taggart and Aleks Szczerbiak, tried to conceptualize Euroscepticism with its all-encompassing approach by contrasting "hard Euroscepticism" and "soft Euroscepticism". In this respect, "the hard" one is labeled as opposition to the European integration process and the EU, whereas its "soft" version presented an idea of disapproval towards one or several EU policies [Taggart, Szczerbiak 2004: 1-27].

In a more defined way, Petr Kopecký and Cas Mudde vary from Europhiles to Europhobes in analyzing the approaches to the European integration and the European Union itself. They present the supporters of the EU and European integration as Euroenthusiasts. Europragmatists become those who are willing to support the EU as such generally; and then there are Eurosceptics, i.e. those who generally support the ideas of the European integration but somewhat express negative opinions about the EU. Finally, the classification presents Eurorejects. They subscribe neither to the ideas underlying the process of European integration nor to the EU itself [Kopecký, Mudde 2002: 302-303].

A bit broader perspective was presented by Chris Flood in his six-point categorization of Euroscepticism. On the one hand, he gives "maximalists" reflecting positively on the process of further European integration. On the other hand, there are rejectionists, totally opposing EU membership and participation in EU processes. There are also "revisionists", trying to return to the status quo before the integration project times; "minimalists" who have a rather positive attitude towards EU achievements but negative towards the new waves of integration; "gradualists", advocating 
for the slow-speed integration; and "reformists", attempting to improve the existing EU developments [Flood 2002: 46].

However, these theoretical approaches could not explain why the tendencies of the EU center and periphery diversity made even a more significant impact than the economic crisis in 2008. In reality, coinciding with migration challenges, the motivations to use the EU institutions to advocate for proper interests is what becomes realistic nowadays. Therefore, some of the scholars tried to go beyond the traditional way of interpreting Euroscepticism. Eugenio Salvati argues that contemporary Eurosceptic opinions might be very much linked to the idea of populism in EU countries. In such a way, political parties of the member states manifest their unwillingness to consider the European Union as a political actor, since it is "the product of non-recognized political system" [Salvati 2016].

Moreover, Catherine De Vries presents a new cutting-edge approach towards how public opinion matters in understanding the EU and European integration. In her book, she dwells on multi-facet Euroscepticism which can target the European integration process depending on how national institutions and policies respond to citizen's views of the EU. She breaks the conventional idea that Euroscepticism is a mono-conceptualized response [De Vries 2018: 26-28].

In this regard, Liubomir Topaloff makes a conclusion about national political actors regarding their decision-making that tends to adopt rather an anti-EU position than the pro-EU one instead. According to this scholar, political elites believe that current EU modus operandi is not confident enough for the current depth of integration to be satisfactory. In such a way, he stipulates that too much or too less EU integration prompts nations and political elites consider it as a variable that tends to go further on the negative curve [Topaloff 2012: 23-24].

\section{ITALY'S PATH FROM EURO-OPTIMISM TOWARDS EUROSCEPTICISM}

Italy's participation in the development of the provisions of the Maastricht Treaty, the conduct of all intergovernmental conferences, namely during the Italian presidency in the EU, concluded with the signing of the necessary treaties of the EU (Maastricht and Amsterdam), identified the critical role and place of this country in shaping European politics in the early 1990s.

These treaties included not only the completion of the creation of a common internal market; monetary, economic, and customs unions; monetary, political integration; and the creation of a military-political alliance. Besides, it was about preparing for the processes of deepening and expanding European integration and the EU as a whole [Vdovychenko 2013: 79]. The principles of deep integration laid down by the Maastricht and Amsterdam treaties are subject to numerous discussions at the beginning of the $21^{\text {st }}$ century. However, it was the Italians themselves who remained the largest Euro-optimists in the EU. 
The historical connection between Italy and Europe has always determined the priority of pro-European affairs over national issues. Within Italy's case, it is stipulated that the Italians not only appraise the EU through national lenses, but also analyze the local achievements through the prism of European developments [De Vries 2018: 28].

Italy's national transformations at the beginning of the 1990s, leading to the establishment of the Second Republic, prompted newly-born parties to elaborate new approaches towards EU institutions and European integration as a process. Thus, since the advent of the Second Republic governance, a new chain of politicians announced a change in the governing system towards more responsiveness to post-Maastricht Treaty challenges. Moreover, considered as a Euro-enthusiastic nation, Italians perceived the process of European integration rather as a "political benefit" for Italian society. Both geopolitical interests and outcomes from being in the EU explained the support of the EU integration processes. Italians presented quite positive approaches towards the European integration process in before- and after-Maastricht treaty years [Vdovychenko 2012: 28]. This approach was based on a straightforward logic: holding a somewhat negative perspective of national elites, the Italians considered European institutions more powerful to implement effective policies and receive proper responses.

In recent years, the EU crisis and austerity measures introduced were prompting to "uncork the bottle" of the Eurosceptic front, leading to the emergence of new parties that are opposed to the process of integration. The point of no return for Italy were European parliamentary elections in 2014 and consequent national voting in the Matteo Renzi's referendum on December 4, 2016. Euroscepticism became common ground to surge due to the emergence of a new dimension of political competition in Italy and the EU. Moreover, shadows of "external forces" including migration and asylum crisis in 2015 raised serious concerns over EU's ability to effectively respond to the prevailing political issues [Mauro, Memoli 2016: 32-33]. In the UK, Brexit opened the "Pandora box" to reflect about EU prolonged legitimacy crisis.

Even in 2018, Italian politicians and scholars are polarizing around two further directions of the European Union's development, in particular: through further and deeper integration or, conversely, disintegration, that is, the weakening of existing ties between EU member states in certain spheres. Prime minister of Italy, Paolo Gentiloni spoke on the importance of further integration in 2015, during the conference organized by the Italian Institute for International Political Studies. He noted that the future of Europe would depend on the ability of States-states to regenerate interactions and the desire to overcome the frustration associated with the slower pace of European integration [Gentiloni e Gozi in ISPI: il ruolo dell'Italia nel future dell'Ue 2015].

At the same time, the evolutionary changes in EU countries with a multi-party system of governance began even earlier. Accordingly, Italy, one of the founding fathers of the EU, felt the unprecedented growth of non-systemic political forces formed into populist movements. In addition, populism in the Italian Republic was 
also referred to as "national", since the Italian political circles began to favor the idea of gradual disintegration and the weakening of relations with Europe [Lanzone, Woods 2015: 56].

The national governmental challenges affected most the Italian mindset to raise concerns about the systemic inefficiencies that Italy produced for its citizens. The legislative measure to drive democracy towards a more majoritarian model produced even more disappointment. Moreover, the fact of being incapable of changing power in order to govern more efficiently, made Italians think that the shift to the Second Republic was a pure illusion [Marangoni 2013: 108]. Thus, frequent intergovernmental conflicts and disputes showed the incapacity for the Italian politicians to deliver grass-root challenges not only to the national but also to the European institutions.

As for the external challenges for Italy at the beginning of the $21^{\text {st }}$ century, it is necessary to consider the feeling of being vulnerable and inflexible to new globalization challenges. Taking into consideration the global crisis, the Italian Republic remains the leading economy in the world and the third largest economy of the Eurozone. Unlike other states in the Mediterranean region, its economy is somewhat diversified, which gives it the preference to adapt, albeit not immediately, to the economic challenges of the EU. The political salience of becoming pro-European as a backbone for the country development and identity is presented in the study by Fabio Serricchio. He tries to demonstrate the changing variable that impacts on how nations attribute themselves to the EU, European integration process and its future [Serricchio 2012: 117-118]. In such a way, he measures to explain the growing sense of why Italians are increasing their disaffection towards European integration.

In this regard, it is necessary to draw a line between Euroscepticism and populism. Flavio Chiapponi [2008] present several features of populist engagement into the process, merely a desire to have strong leadership to overcome existing economic, social and political issues as well as the demonstrative intolerance to the existing institutions. Moreover, this political scientist present the idea that personalization of populism is the outcome of the simplification of the populist rhetoric trying to offer the answers to all the challenges.

The populist mentality reflects its "black-and-white logic": from realistic ideas of people to more idealized, from perceiving the realities of current political, economic and social challenges per se as basic points towards an open aversion to the existing challenges and intolerance towards institutional means to address them. Special to Italian case remains a greater variety of this way of thinking, presenting rather a chameleonic character attributed to specifically Italian populism used by both right and left political parties. Therefore, it is quite clear why Italian populists also attack the mechanisms of direct democracy. Aversion to national or EU institutions, which have not committed themselves to following the nations' will, and far distance from people, made populists demand that the political decision-making process stands for the people's will. At the same time, it is an interesting observation that populists use the critique of the democratic institutions not to deny the democratic principles. 
They would rather reestablish their populist narratives to compensate an increasing demand for democratization between institutions and citizens and in such a way paying more and more attention to the issue of Euroscepticism in Italy.

Following the logic of Topaloff, both national and EU political parties are the primary driver of policies and politics in European democratic systems. The scholar considers them as the most critical challenges of spreading Eurosceptic agenda [Topaloff 2012: 5]. It is a highly contentious topic whether economic problems fostered the spread of populism and skepticism in Italy. However, we expect that the ideological profile of the Italian Eurosceptic parties determines a particular approach in reflecting over the EU. Therefore, we formulate a hypothesis (H1a) that the populist parties in Italy, being linked to the governing right-wing rhetoric, prefer to have a more radical approach towards the structures of the EU, putting under pressure the principles of its governance; $(\mathrm{H} 1 \mathrm{~b})$ Left-wing populist parties tend to criticize the EU as well, but not its governing principles.

A more elaborate study should examine the specific conditions that prompt Italian political "elites" to open their anti-EU rhetoric. The Italian manifestation targeting the European integration issues rose due to their populist anti-EU point of view, gaining more positions in the governments. However, the economic challenges were the first for the Italian citizens to raise concerns about EU policies implementation in their country. Being low-productive and low-growth scale country before the crisis, in 2008 Italy became among "the biggest among the weakest" member states with enormous debt-to-ratio GDP of $102.4 \%$ [Country Economy Debt: Italy National Debt 2008] an increasing level of unemployment, especially among young people, it fostered inequality, and social changes made an impact on the party systems and their narratives. At the same time, having a multiparty system, Italy immediately received messages from its society to penalize the existing political authorities [Toygur 2018: 1-2].

Another point of view in favor of Eurosceptic agenda is the fact that economic benefits became a pivotal determinant for the citizens to orient their approaches in support or not towards European integration. Evis Mezini stipulates that citizens analyze their cost-benefit trade-off related to their welfare gains and losses and associate them with the EU efficiency [Mezini 2014: 19-20]. Starting from the times of Mario Monti being the prime minister of Italy, his austerity measures were supported in Germany and France but failed to be understood by the Italians. The figures about the Italians' trust in the EU, and political parties reached its lowest point in the period of 2012-2014 [Toygur 2018: 5-6]. At the same time, the "Achilles heel" in Italy still remains to be good governance and public administration due to its historic legacy. Starting from the 1990s, for the third decade, Italy is experiencing a "reform path", when the need for effective reforms has numerous political and economic barriers.

It is possible to agree with an Italian scholar Andrea Pirro that Italy is having its unique form of populism - polyvalent populism, which combines supporting numerous ideological discordances, newness, and radicalness [Pirro 2018: 443]. In his 
analysis, Pirro points such a tendency related to the Five Star Movement. However, such a trend is apparent also for the League and Five Star Movement presented by the discourse of Matteo Salvini and Luigi Di Maio. For example, numerous far-right and far-left rhetoric is displayed in the announcements and vision for the EU from both party leaders, where one is coming with the "enemies of Europe" [Salvini: Juncker and Moscovici are 'enemies of EU'2018] strategy for the current EU leaders, the other - with giving the diagnosis for the EU "to live only for six months" [Di Maio attacca (ancora) l'Ue: "Gli squali sentono il sangue e azzannano" 2018]. However, both of the leaders, in practice, contradict the "yellow-green" coalition agreement where the aim of the EU-Italy cooperation is based on the genuine respect of the EU institutions as well as EU partners.

So, the steps taken in order to take the country out of economic crisis prompted Italians to think about their political leaders as inactive and reluctant to deal firstly with national issues rather than European ones. At the same time, the "EU issue" provided the Italian small (and sometimes peripheral) political elites with the opportunity to gain control over the direction of the debate implementing their agenda.

\section{M5S AND LEGA: WINNING RATIONALE}

The elections in 2018 demonstrated that anti-establishment movements shaped the majority of the Italian mindset. M5S did not just become a leader but also got more than predicted by the exit polls. The right-wing radicals from Lega (Lega Nord) also obtained very good results. Together, these Eurosceptic parties receive more than half the votes in both houses of parliament. Instead, both traditional political forces failed. Moreover, the center-left wing of the ruling Democratic Party (PD), and the center-right Forza Italia, led by Silvio Berlusconi, received less than they had expected.

The politics in Italy is still weak due to the dissolution of innovation and political transformations to become the real Third Republic. The role of leadership in Italian politics was always crucial for determining how people's choices shifted the interests of political parties. This time, the winning rationale was around two models of party organization in Italy - "the leader with the party" (case of Matteo Salvini and Lega) as well as "the party with the leader" (case of M5S, where a newly elected leader Luigi Di Maio was firstly unrecognizable for voters for maverick M5S).

Five Star Movement (Movimento 5 Stelle, M5S) is one of the front-runners of this year's elections in Italy having left-wing ideological preferences. Established by a TV comedian Beppe Grillo and a web-developer and strategist Gianroberto Casaleggio, M5S became the first anti-establishment party in Italy to form further the current government based on the discourse of the direct democracy [Bordignon, Ceccarini 2013: 691]. It criticizes the European Union for its inability to support Italy in the economic crisis as well as for social inequality that led to imbalances 
in terms of providing aid to Italy. The M5S also provided its critics to the left-wing government led by Prime Ministers Renzi and Gentiloni. The party gained second place during the EP election in 2014 [EP results ... 2014]. Some of the researchers in 2014 continued to think that left-wing parties would be even strongly supported by the nation and win key mayoral seats in 2016 and 2017 even for those cities which were left-wing for decades [Segatti et al. 2015: 327-328]. Meanwhile, some other scholars indicate that M5S' sentiments towards Euroscepticism imply its opposition to the EU austerity measure. At the same time, between 2014 and 2016, M5S claimed to be one of the most pro-EU party in Italy [Franzosi et al. 2015: 113].

The League (or Lega Nord (Northern League) till 2017) remains Italy's far-right and still second-largest anti-establishment party. Representing somewhat Northern Italy constituency and being, as a result, traditionally anti-southern party, promoting secession of Gran Padania region, it made some major transformation under its leader Matteo Salvini. Lega refused its South-regional criticism, toughened its position towards European integration and Eurozone and continued liaison with other far right populist parties in Europe [Longo 2016: 16]. Moreover, it crafted its narratives in such a way that even Southern Italians voted in favor of Lega due to the promises to find responses to total insecurity, unsolved migration flows and populist concerns about loss of Italian identity due to the outcomes of globalization. ${ }^{1}$

The reasons for the anti-establishment parties winning "hearts and minds" of Italians encompasses national and foreign challenges. The specifics of this year's Eurosceptic winners consists in the fact that none of them wanted Italy to leave the EU. Also, even the most radical of them, Lega, removed from its program the narrative to be "all against all". The two previously largest political parties, PD and Forza Italia, were generally considered pro-EU. However, even in their rhetoric, in particular in the PD program, it is possible to find Eurosceptic narratives aimed at receiving more voters and their attention [Programma ed indicazione... 2018: 1-2]. Italian politicians mostly criticize policies inside the Eurozone, because they see that the euro currency does not help the Italians to overcome the 134\% debt of GDP that Italy owes to the EU. Moreover, the World Bank data indicate that Italy's economic development is one of the lowest in the EU (only 1.1\%) [World Bank Report 2017].

It is necessary to do the mapping of the Italian parties according to their ideology. We operate with the data provided by the Cattaneo Institute to present that $\mathrm{M} 5 \mathrm{~S}$ is relying on the left-wing political and populist logic, while Lega is a far-right populist party.

1 The policy of Lega was to close the majority of its official program documents to the researchers from Ukraine and to put them in the black list. The ban started to be in action since 2018 . 


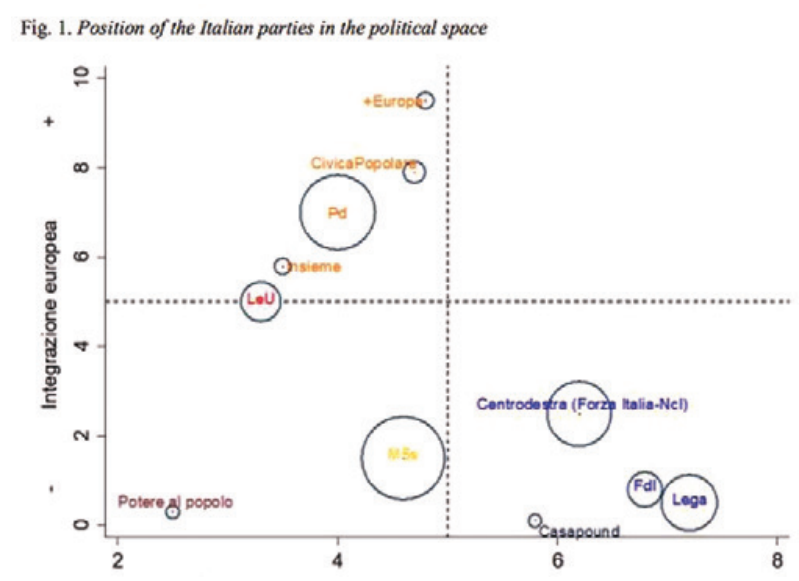

Fig. 1. Position of the Italian parties in the political space

Source: Electoral compass for the 2018 Italian general elections [2018].

We are presenting our personal research of the political agenda before the elections. The key components for the populist logic are given in enlightening three areas: attitude towards the EU, economic challenges and migration issues (Table 1).

In the logic of the Lega program documents, the EU should be revised and changed in shape due to its excessive bureaucracy. The austerity measures introduced to Italy in 2011 and continued to have an impact on the Italians even in 2018, made a point present in the Lega program document that EU institutions should be revised [Programma elettorale. Programma di Lega. "Un Programma per l'Italia” 2018: 4]. Moreover, it continues to be one of the points which populistically keep people voting for Lega in the regional and local elections continuing in 2018 and 2019.

Being supported by the major industrial group from the North of Italy, the logic of Lega is to encourage and facilitate doing business. Some of the steps in the program are presented in order to attract more young Italians into Lega. In this respect, the party engaged a lot of social media posts (if President Trump is the king of Twitter, Salvini is the king of Facebook).

At first glance, the skepticism of M5S towards the EU is less evident. However, this party wants to focus on the measures to avoid the impact of the Eurozone on Italy taking into account the country's indebtedness and the EU criteria restrictions for its member states. The primary focus is devoted to the social expenditures on traditional (for Southern Italy) aspects: trade unions, shortening of the working day, part-time job opportunities [Programma elettorale del Movimento 5 Stelle, 2018: 1-2].

Interestingly enough, the parties found common ground in terms of taking out Forza Italia and Silvio Berlusconi himself from the coalitioning on the point regarding the EU [Governo Salvini, addio per sempre... 2018]. Therefore, Berlusconi decided to follow his independent way towards the European parliamentary elections in May 2019. 
However, both of the parties, Lega and M5S, are similar in interpreting migration challenge from the Italian perspective: from the issues of deporting illegal migrations presented by Lega to the distribution of asylum seekers across the EU, from the M5S. Both of the approaches were introduced in the coalition document from Lega and M5S and became a point of fierce rhetoric from the EU and its partners.

In general, to summarize the points of the program from Lega and M5S, we present a generalized approach on the basis of the Ipsos, Istituto Cattaneo, EAP Hong Kong data as well as of personal interpretation.

Table 1. Who stands for what?

\begin{tabular}{|l|l|l|l|}
\hline \multicolumn{1}{|c|}{ Party } & \multicolumn{1}{|c|}{ Europe } & \multicolumn{1}{c|}{ Economy } & \multicolumn{1}{c|}{ Migration } \\
\hline Lega & $\begin{array}{l}\text { Revise treaties, refuse over- } \\
\text { regulation, no more austerity } \\
\text { policies from Europe, protect } \\
\text { big industrial groups }\end{array}$ & $\begin{array}{l}\text { Facilitate credit lines for } \\
\text { SMEs, help young people } \\
\text { access labor market }\end{array}$ & $\begin{array}{l}\text { Deport illegal migrants, take } \\
\text { control of borders, Marshall } \\
\text { Plan for Africa }\end{array}$ \\
\hline M5S & $\begin{array}{l}\text { Find alternatives to the euro, } \\
\text { strike alliances with southern } \\
\text { European countries, oppose } \\
\text { austerity policies, protect } \\
\text { "Made in Italy" }\end{array}$ & $\begin{array}{l}\text { Free trade union representa- } \\
\text { tion, worker participation } \\
\text { in decision-making, shorten } \\
\text { working day, incentivize part- } \\
\text { time work }\end{array}$ & $\begin{array}{l}\text { Revise the Dublin Regulation, } \\
\text { distribute asylum seekers } \\
\text { across the EU }\end{array}$ \\
\hline $\begin{array}{l}\text { PD } \\
\text { (Democratic } \\
\text { Party) }\end{array}$ & $\begin{array}{l}\text { More European political and } \\
\text { social integration }\end{array}$ & $\begin{array}{l}\text { Reduce unemployment to } \\
\text { under 9\%, youth unemploy- } \\
\text { ment below 22\%, guaranteed } \\
\text { minimum wage, equal pay for } \\
\text { women }\end{array}$ & $\begin{array}{l}\text { No to the Dublin Regulation, } \\
\text { stop aid for countries refusing } \\
\text { to share burden }\end{array}$ \\
\hline
\end{tabular}

Source: Istituto Cattaneo, Ipsos, EAP Hong Kong and author's own analysis.

At the same time, it is necessary to understand that public money was supposed not only to support the inequalities in private and public entities, balance for extensive tax evasion but also to manage social imbalances of all levels. Therefore, the EU is demanding to decrease Italy's public debt which, according to Beda Romano, is, in fact, an attempt to influence Italy's social order established after the Second World War. In fact, the political scientist stipulates that Brussels' demand to stop the economic weaknesses led, in fact, to weakening Italy's possibility to use its public debt. Moreover, Italy did not receive the opportunity to redistribute wealth as it happened for decades before, even not in the most efficient way [Romano 2018: 2].

Secondly, the Italians are opposed to the migration policy of the EU under the leadership of Germany. In recent years, Italy has become the gateway to Europe for migrants of diverse national origin: every year, many African and Syrian refugees seek to cross the Mediterranean Sea and find a better life in Italy and other EU countries. The majority of the migrants try to reach Europe from the African continent via a sea route from Libya to Italy. Italy remains one of the countries that are suffering from the majority of the refugees as a first arrival country. The influx of migrants who have no right of entry and residence permits triggered political and 
social responses by the government led by Letta, Renzi and Gentiloni [Attina' 2017: 167-168]. However, Italy did quite well in terms of saving lives at sea, but did not succeed in integrating migrants, which led to clashes in various cities and further disappointment of the PD-formed coalition government. In their electoral campaigns, Forza Italia raised concerns only about "social time bomb" that migrants represented for the Italian society, M5S insisted on closing the Italian borders for migrants, while PD presented the ways how to redistribute refugees to other EU countries.

Thirdly, in line with other populist parties, M5S and Lega touched the most of frustrated social groups: the young and the educated. Moreover, a very high youth unemployment rate in Italy explains the M5S protest vote [ISTAT 2017; Il Sole 24 Ore 2018]. Recent figures of $31.9 \%$ of unemployed youth indicate that even in 2018 Italy is in the top 3 with the highest youth unemployment rate together with Greece and Spain [Statista 2018]. The EU report on Employment and Social Developments in Europe (ESDE) indicates that one in five young Italians is neither employed nor in full-time study, putting Italy into the top countries within the NEET classification (not engaged in education, employment or training) [ESDE 2017: 37-38].

Having a disadvantage regarding investments, means of social mobility, employment opportunities, and lodging, these "youngsters" would like to "count on something" to address the lack of access to the political decision-making of the parties that fail to perceive their demands and needs [Bonanomi et al. 2018: 184-186]. At the same time, only $35 \%$ of young Italians would like to go into details of "who is who" in Italian politics, while $40 \%$ are not interested in that issue at all. However, the presence of the new faces taking part in the campaign convinces those who are interested in voting in favor for M5S [La Rocca 2018]. Voicing dissatisfaction with Renzi-Gentiloni's governance in 2016-2018 meets the expectations of young Italians, Lega also adapted its messages to attract more young people. Via the "2.0. communication" channels, Lega raised its youth support much more than it used to be in previous elections [Magnani 2018]. According to the agency Ipsos, it gave very positive results in terms of attracting more young people in favor of Lega after elections [Sondaggio Ipsos... 2018].

In general, it leads to a conclusion that Italian populism, presented by the new governing parties, voices dissatisfaction of young and the middle-aged Italians willing to see the changes in their regions and their businesses.

\section{IN LINE WITH YELLOW-GREENERS: WHAT'S NEXT?}

The long-awaited coalition of M5S and Lega turned out to be an interesting political experiment for Italy after almost three months of expectations during national March's elections. M5S and Lega still disagree on many issues but they share their views in terms of placing responsibility on the European Union for Italy's current position. 
Another Italian "yellow-green" government (with apolitically chosen but in fact "technical" prime minister) demonstrates the new "political techniques" for Italy: for the first time, it breaks with the Italian tradition when the leader of the ruling or coalition party has always been the prime minister. This time, both leaders, from M5S and Lega did not want to compete each other and agreed to a neutral candidate, however, still nominated by the M5S.

The Italian future is outlined in the 40-page "Italian Program of Change" which combines the slogans of the left and right directions. It refers to the closure of Roma camps, the strengthening of law enforcement and the protection of victims of crime, as required by the Lega demands. Instead, the content of the "leftist" provisions stands for increasing social benefits and the abolition of the pension reform of 2012, which raised the retirement age. At the same time, the Coalition "Program" presented the allegations to violate fiscal and financial limits imposed by the EU for the Eurozone countries [Contratto per il governo del cambiamento 2018].

Concerning the EU affairs, the idea of the "yellow-green" government of Italy sounds like an attempt for a significant reshuffle of European governance, in favor of bringing sovereignty back to Italy and, at the same time, effectively undermining the European integration. These new messages, which are about further lack of tolerance towards immigrants, the challenges of remaining in the Eurozone, etc., are likely to be found in every corner of Italy experiencing a high rate of unemployment, economic decline and societal insecurity [Longo 2016: 11].

The "yellow-green" government announced three social initiatives for 20192021: the introduction of a minimum income for low-income citizens (the key program idea of the Five Star Movement), a reduction in tax pressure, and a reduction in retirement age due to the abolition of the so-called "Fornero Law", which raised the retirement age [Testo di Bilancio 2019 ufficiale: 11].

Also, although the negative balance of $2.4 \%$ of GDP does not exceed the European norm of 3\%, in a situation of excessive public debt, the European Commission demands from Rome a very conservative fiscal policy. In particular, the new government should reduce the budget deficit by "cutting off" large-scale social expenditures from planned expenditures.

Moreover, here the Italians will have to think something much more creative than the "twine" policy between the populist position of the leaders of the M5S and the Lega, on the one hand, and the fiscal requirements of the Stability Pact, on the other, as the European Union requires.

It should be explained that Matteo Salvini, the newly appointed Minister of Interior of Italy who took office just at the beginning of June, has already adopted a policy to block any foreign humanitarian boats coming to Italian ports. As a result, Italy started to have political tensions with France and the Netherlands. Salvini refused to give permission to dock for the ship Aquarius (June 11, 2018) that had representatives of Doctors Without Borders (Médicins Sans Frontières) as well as other humanitarian organizations working with refugees 
coming from Libya [Aquarius, cosa ha ditto il ministro Salvini nel suo intervento al Senato 2018].

In this regard, the Italian Republic itself advocated celebrating the $60^{\text {th }}$ anniversary of the signing of the Rome Treaties, which defined European integration and contributed to the transitory way from being European Community to the European Union. The Rome Treaties became fundamental to the creation of the Europe of nations after the Second World War. They defined the priority of the rule of law, democracy, and four freedoms: the free movement of people, capital, goods and services [Vdovychenko 2017: 18-19]. However, it is quite disputable whether such rhetoric will be supported by the "yellow-greeners" in the upcoming years.

The unusual relation of M5S and Lega in forming a government creates new époque, raising concerns also for the further European integration project. In particular, an alarm button presents Salvini's program statements to substantially increase Lega's presence and try to become a champion candidate in the European Parliament during the May 2019 elections. This recent episode nicely illustrates that the debate about the EU will be for the politicians to present "new verbal qualifications" if they want EU to continue its transformation, and not a decline process. So if Salvini succeeds, such an operation will generate the epochal change both in the international chessboard and in terms of the values and internal rules of the European Union.

\section{CONCLUSIONS}

Eurosceptic realities are not a new phenomenon in Italy but are successfully spreading over Italy where the new political parties efficiently channeled the social discontent of Italians. Across the country, the disenchantment with the EU mirrors the willingness to see new faces instead of the old political class. The migration crisis, high unemployment rate and a dwindling level of trust in Italy's institutions were some of the most significant barriers for the Italian "left-wing" parties to remain in power. The confrontation between "old parties" - Forza Italia, PD - and the rebranded or new ones - M5S and Lega - demonstrated the desire to have an active political elite. In this regard, Italy chose the line towards more populist and Eurosceptic parties at the same time. M5S and the Lega proposed highly exaggerated ideas but gave an impression of building a certain autonomy regarding the bureaucratic EU.

The attitudes towards the EU became a disputable issue in many of its member states. Being traditionally pro-EU, Italy is experiencing a decline in supporting the European integration process. On the governmental level, it is also being done by the new "yellow-green" government. We agree that the economic crisis in Italy and the austerity measures imposed both by the previous government run by the Democratic Party and supported by the EU, fostered the new Eurosceptic and fully populist parties to come to power. Furthermore, we observed that the ideological orientation of the parties (whether it is a right-wing or left-wing) still keeps their EU-sceptic party 
agenda. By analyzing the program documents and coalition agenda, we tried to prove that the Lega's right-wing rhetoric is anchored in its more radical approach towards the EU. We concluded that such Lega's modus operandi is caused by the willingness to keep the voters on track because the electoral campaigns in the Italian regions and provinces continue and Lega is also seriously preparing for the EU parliamentary elections. Meanwhile, Five Star Movement continues being Eurosceptic as well, but criticizes its institutional principles in comparison with Lega. We have to underline that the choice of only these two Italian parties was made due to one more aspect that they communicate in the Italian arena - a particular nationalistic approach addressing the EU. Further analysis and research are needed to empirically prove more traits of populism related to the new and old Italian parties in 2019.

After the Brexit referendum, Italy proved that EU member states embody different approaches towards its future. Eurosceptic political actors prove to voice more and more nations with their asymmetric but still relevant to the hearts of the electorate messages. This process can provide a significant impact on possible fundamental shifts in the European Parliament elections in May 2019. In such a way, the EU politicians will have to develop a simple taxonomy to categorize the arguments to remain pro-European.

\section{BIBLIOGRAPHY}

Aquarius, cosa ha ditto il ministro Salvini nel suo intervento al Senato, 13.06.2018, https://www.tpi. it/2018/06/13/salvini-aquarius-francia/ (access: 28.07.2018).

Attina', F. 2017. Oltre il Migration Compact: la gestione italiana della crisi migratoria, [in:] L'Eta'dell'incertezza: Scenari globali e l'Italia, A. Colombo, P. Magri (eds), ISPI Rapporto, Milano.

Bonanomi, A., Migliavacca, M., Rosina, A. 2018. Domanda di rappresentanza e orientamento politico, [in:] Rapporto Giovani 2018 - la condizione giovanile in Italia, Istituto Giuseppe Toniolo, Il Mulino.

Bordignon, F., Ceccarini, L. 2013. The 5 Star People and the Unconventional Parliament, "Studia Politica: Romanian Political Science Review", vol. 13 (4), pp. 675-692.

Chiapponi, F. 2008. Il populismo come problematica della scienza politica, Mauro Cormagi Editore, Genova.

Contratto per il governo di cambiamento, 2018, http://download.repubblica.it/pdf/2018/politica/contratto_governo.pdf (access: 19.01.2018).

Country Economy Debt: Italy National Debt, 2008, https://countryeconomy.com/national-debt/italy?year=2008 (access: 27.07.2018).

De Vries, C. 2018. Euroscepticism and the Future of European Integration, Oxford University Press, Oxford.

Di Maio attacca (ancora) l'Ue: "Gli squali sentono il sangue e azzannano", "Il Giornale", 7.10.2018, http://www.ilgiornale.it/news/politica/maio-europee-ci-sar-terremoto-contro-lausterity-questa-ueha-1585048.html (access: 06.01.2019).

Electoral compass for the 2018 Italian general elections, 2018. Istituto Cattaneo, March, https://www.cattaneo.org/wp-content/uploads/2018/03/Istituto-Cattaneo-Overview-of-the-2018-Italian-general-elections-8-March-2018.pdf (access: 16.01.2019).

Employment and Social Developments in Europe (ESDE). 2017. Annual Review 2017. European Commission Directorate-General for Employment, Social Affairs, and Inclusion Directorate A, Publications Office of the European Union, Luxembourg. 
EP results of the 2014 European elections. European Parliament, 22.09.2014, http://www.europarl.europa. eu/elections2014-results/en/country-results-it-2014.html (access: 27.07.2018).

Flood, C. 2002. The Challenge of Euroscepticism, [in:] The European Union Handbook, J. Gower (ed.), Fitzroy Dearborn, London-Chicago, pp. 73-84.

Franzosi, P., Marone, F.,Salvati, E. 2015. Populism and Euroscepticism in the Italian Five Star Movement, "The International Spectator", vol. 50 (2), pp. 109-124, DOI: https://doi.org/10.1080/03932729.20 15.1030273 .

Gentiloni e Gozi in ISPI: il ruolo dell'Italia nel future dell'Ue, 6.03.2015, http://www.ispionline.it/en/ node/13253 (access: 25.07.2017).

Governo Salvini, addio per sempre a Berlusconi. Ecco il progetto della Lega, 8.11.2018, http://www. affaritaliani.it/politica/governo-salvini-addio-per-sempre-a-berlusconi-ecco-il-progetto-dellalega-571034.html?refresh_ce (access: 16.01.2019).

Il Sole 24 Ore, 13.03.2018, http://www.ilsole24ore.com/art/notizie/2018-03-13/istat-disoccupazione-2017-112percento-minimo-4-anni--100910.shtml?uuid=AE2nV2FE (access: 27.07.2018).

ISTAT. Disoccupazione mensile, 2017, http://dati.istat.it/Index.aspx?DataSetCode=DCCV_TAXDISOCCUMENS1 (access: 27.07.2018).

Kopecký, P., Mudde, C. 2002. The Two Sides of Euroscepticism: Party Positions on European Integration in East Central Europe, "European Union Politics", vol. 3 (3), pp. 297-326, DOI: https://doi.org/10 $.1177 / 1465116502003003002$.

La Rocca, O. 2018. La sfiducia dei giovani per la politica italiana, 8.04.2018, https://www.panorama.it/ news/politica/la-sfiducia-dei-giovani-per-la-politica-italiana/ (access: 27.07.2018).

Lanzone, M.E. Woods, D. 2015. Riding the Populist Web: Contextualizing the Five Star Movement (M5S) in Italy, "Politics and Governance", vol. 3, pp. 54-64, DOI: https://doi.org/10.17645/pag.v3i2.246.

Longo, M. 2016. Italy's Lega Nord: Changing Poses in a Shifting National and European Landscape, "Australian \& New Zealand Journal of European Studies", vol. 8, pp. 16-30.

Magnani, A. 2018. Perche' Lega e Cinque Stelle hanno conquistato i giovani, http://www.ilsole24ore. com/art/notizie/2018-03-12/perche-lega-e-cinque-stelle-hanno-conquistato-giovani-151445.shtml?uuid=AEuCGZFE (access: 29.07.2018).

Marangoni F. 2013. Provare a governare, cercando di sopravvivere: esecutivi e attività legislative nella seconda repubblica, Pisa University Press, Pisa.

Mauro, D., Memoli, V. 2016. Attitudes Towards Europe Beyond Euroscepticism: Supporting the European Union through the Crisis, Palgrave McMillan, Cham.

Mezini, E. 2014. The Effects of Economic Factors on Public Support for the European Union: Evidence from Experimental and Survey Data, Claremont Graduate University, Claremont.

Pirro, A. 2018. The Polyvalent Populism of the 5 Star Movement, "Journal of Contemporary European Studies", vol. 26, pp. 443-458, DOI: https://doi.org/10.1080/14782804.2018.1519484.

Programma di governo: Salvini, il premier, https://www.leganord.org/component/phocadownload/category/5-elezioni?download=1514:programma-lega-salvini-premier-2018 (access: 19.07.2019).

Programma ed indicazione del capo della forza politica del Partito Democratico, 2018, https://dait.interno. gov.it/documenti/trasparenza/Doc/98/98_Prog_Elettorale.pdf (access: 19.01.2019).

Programma elettorale del Movimento 5 Stelle, 2018, https://dait.interno.gov.it/documenti/trasparenza/ Doc/4/4_Prog_Elettorale.pdf (access: 19.01.2019).

Programma elettorale. Programma di Lega. "Un Programma per l'Italia", 2018, p. 4, https://dait.interno. gov.it/documenti/trasparenza/Doc/5/5_Prog_Elettorale.pdf (access: 16.01.2019).

Romano, B. 2018. Italy's Euroscepticism: A Case of Victimhood and a Tale of Missed Opportunity, 7.03.2018, Jacque Delors Institute, http://institutdelors.eu/publications/italys-euroscepticism-a-case-of-victimhood-and-a-tale-of-miss-opportunity/?lang=en (access: 28.07.2018).

Salvati, E. 2016. The Five Star Movement in the European Parliament. A real Eurosceptic party? ECPR General Conference Prague, https://ecpr.eu/Filestore/PaperProposal/12d4a5f0-8a2a-4d24-afbf-3a5c4b5154a1.pdf (access: 25.07.2018). 
Salvini: Juncker and Moscovici are 'enemies of EU', "EUobserver", 8.10.2018, https://euobserver.com/ tickers/143049 (access: 06.01.2019).

Segatti, P., Poletti, M., Vezzoni, C. 2015. Renzi's Honeymoon Effect: The European Parliament Election 2014 in Italy, "South European Society and Politics", vol. 20, pp. 311-331, DOI: https://doi.org/10. 1080/13608746.2015.1075709.

Serricchio, F. 2012. Italian Citizens and Europe: Explaining the Growth of Euroscepticism, "Bulletin of Italian Politics", vol. 4, pp. 115-134.

Sondaggio Ipsos - Governo Conte con un gradimento del 68\%, ma i suoi ministri sono molto più giù. Bene Salvini e Di Maio, male Savona e Tria, 10.08.2018, http://sondaggibidimedia.com/sondaggio-ipsos-governo-conte-gradimento-68/ (access: 12.12.2018).

Statista. Youth Unemployment Rate in EU Member States as of May 2018, https://www.statista.com/statistics/266228/youth-unemployment-rate-in-eu-countries/ (access: 29.07.2018).

Taggart, P., Szczerbiak, A. (eds.). 2008. Opposing Europe? The Comparative Party Politics of Euroscepticism. Volume 2: Comparative and Theoretical Perspectives, Oxford University Press, Oxford.

Testo di bilancio ufficiale, 2019. Redazione ottobre, 2018.

Topaloff, L. 2012. Political Parties and Euroscepticism, Palgrave Macmillan, London.

Toygur, I. 2018. A Guide to Understanding Italy: The 2018 Elections and Beyond, 16.03.2018, Elcanto Royal Institute, http://www.realinstitutoelcano.org/wps/portal/rielcano_en/contenido?WCM_GLOBAL_CONTEXT=/elcano/elcano_in/zonas_in/ari39-2018-toygur-guide-to-understanding-italy-2018elections-and-beyond (access: 29.07.2018).

Vdovychenko, V. 2012. Out of Crisis with Another Europe: Italian Case, "Foreign Affairs of Ukraine", no. 6.

Vdovychenko, V. 2013. The Role of Italy in Preparing of the Maastricht Treaty (1989-1992), "Gileya", vol. 77, pp. 77-95.

Vdovychenko, V. 2017. Following Continuity and Change: Italy's View on European Neighborhood Policy Towards Ukraine, "The International Relations of Ukraine: Scientific Searches and Findings", vol. 26.

Verney, S. 2011. Euroscepticism in Southern Europe: A Diachronic Perspective, "South European Society and Politics", vol. 16, pp. 1-29, DOI: https://doi.org/10.1080/13608746.2010.570124.

World Bank Report 2017. Italy, https://data.worldbank.org/country/Italy (access: 28.07.2018).

\section{BIOGRAPHY}

Victoria Vdovychenko, $\mathrm{PhD}$, is an Associate Professor and researcher. In her scientific research she deals with the challenges of the European Union, Euro-Atlantic integration, hybrid warfare, strategic communication. She is one of the team members for the Professional Governmental Association (PGA) which aims to enhance Ukraine's governance system by providing advisory support to the governmental institutions. She is heading PGA Diplomatic Initiative. E-mail: vdovychenkov@ gmail.com 